\title{
HBB NP_000509.1:p.E7V
}

National Cancer Institute

\section{Source}

National Cancer Institute. HBB NP 000509.1:p.E7V. NCI Thesaurus. Code C156905.

A change in the amino acid residue at position 7 in the hemoglobin subunit beta protein where glutamic acid has been replaced by valine. 